\author{
Salvador Angosto* \\ Associació de Veïns i Veïnes del Bon Pastor \\ Barcelona, Spain \\ juanamelenchon@hotmail.com
}

\title{
MAPPING THE HISTORY OF A TERRITORY: BON PASTOR (BARCELONA) - SOCIAL REMEMBRANCE AND HERITAGE PROJECT
}

\begin{abstract}
The topic of the article are the complex stages of the formation of the Bon Pastor neighbourhood in Barcelona, and contemporary efforts to create the remembrance space system that would preserve the social memory and historical identity of the place. The author presents how the urban development plans for the district were transformed as a result of major changes in national politics, economy, and social policy, since the 1930s, through $60 \mathrm{~s}$ and $70 \mathrm{~s}$, till today. The article describes the Bon Pastor Civic Memory project as an interesting example of a participatory action aimed at the preservation of local heritage.

The implementation of the Civic Memory project was possible due to the neighbours' initiative and their cooperation with cultural and academic institutions. The aim of this project is to mark certain points of the territory which possess historically and socially significant value, and to enhance them through public art, urban design and other implementations envisaged. The Association of residents of Bon Pastor (Barcelona) has been characterized, since 1974, for its combative and vindictive nature, at the same time as for its great capacity to launch solidarity initiatives and manage complicated processes to improve the living conditions of residents of the neighbourhood. After the struggles to obtain a health centre, the improvement of communications by metro and bus, and the constant improvement of public space, in recent years, the Association is co-managing with the Barcelona City Council, the radical transformation of the neighbourhood. The different phases for the remodelling of the neighbourhood, by replacing the so-called "cheap houses" with new buildings, with more spacious apartments and with better material conditions, is coming to an end and now, the possibility opens up, driven by the neighbours and the Museum of the History of the City (MUHBA) to have a metropolitan museographic space devoted to the presentation and study of the evolution of workers' and popular housing in Barcelona.
\end{abstract}

\section{Keywords:}

Barcelona, Bon Pastor, participation, remembrance

\footnotetext{
* Salvador Angosto is an activist, the former president (1975-1980) of the Associació de Veïns i Veïnes del Bon Pastor Barcelona, Spain. He is a Catalan trade unionist and local leader born in a family resident in the Casas Baratas in the Bon Pastor district of Barcelona. He has been greatly engaged in social and political activism focused on improving the living conditions of the neighbourhood and also focused on maintaining the memory and consolidating the historical identity of this area. He gives lectures on the heritage of the Bon Pastor district. He participated in the $3^{\text {rd }}$ International Conference Aesthetic Energy City. Urban Polarities organised by the University of Lodz (Department of Ethics, Institute of Philosophy and Ceraneum Centre), the University of Barcelona (Polis Research Centre) and the Urban Forms Foundation on October 25-27, 2018 in Łódź.
} 


\section{CONTEXT}

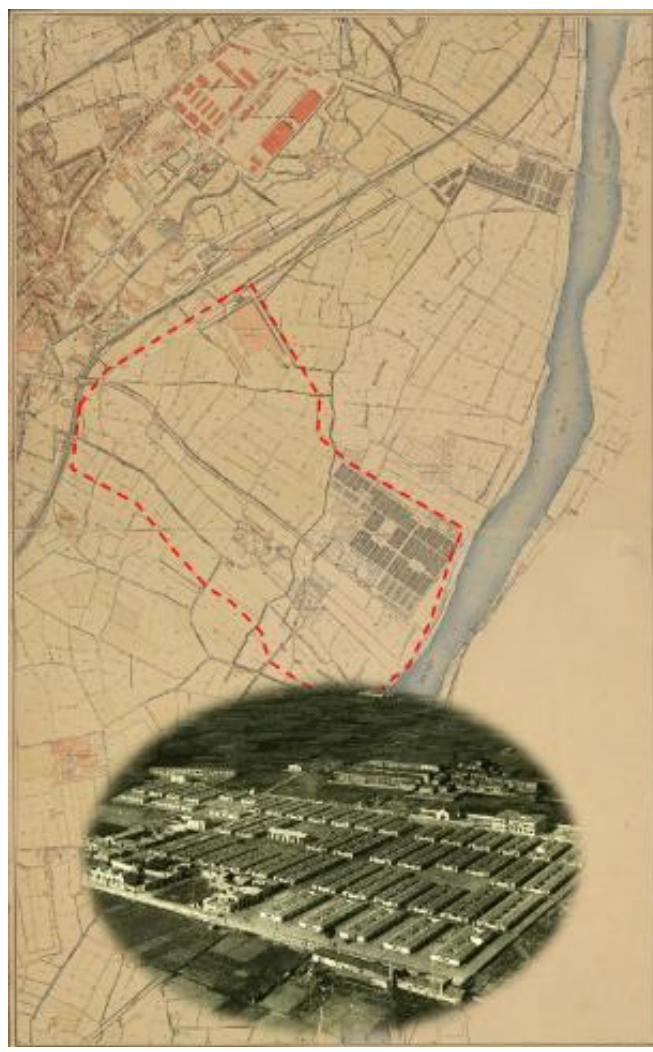

Fig. 1. Red points mark the territory of Bon Pastor neighbourhood. In the image: the Milans del Bosch group. Barcelona topographic plant c.1930 and aerial photo of the Milans del Bosch group.

Source: ICGC [Institut Cartogràfici Geològic de Catalunya].
Bon Pastor is a neighbourhood located in the North-East of Barcelona on the banks of the Besòs River and integrated in the Sant Andreu district. At the beginning of the Second Industrial Revolution, some large companies [Can Sala, 1905; Sanchís Industries, 1907; Maquinista, 1918] were settled in the territory, attracting working population to the small neighbourhoods of Estadella, Sanchís, Carolinas, a rural and agricultural environment. The territory of the actual Bon Pastor was split between the municipalities of Barcelona and Santa Coloma de Gramenet. Until 1944 Santa Coloma remained an outside territory to Barcelona. In 1929, in the context of the International Expo of Barcelona and within the framework of Spanish legislation (the 1921 Low-Cost Affordable Homes Act, known as Casas Baratas $^{1}$ ), the Municipal Housing Board (PMH) ${ }^{2}$ built a group of 784 single-family houses in row (El grupo fue llamado Milans del Bosch (fig. 1)). ${ }^{3}$

\footnotetext{
${ }^{1}$ The literal translation of this concept is "cheap houses."

${ }^{2}$ Not far from there, at about $600 \mathrm{~m}$, the PMH also built another smaller group: Baró de Viver. It received the name of Darius Romeu, Second Baron of Viver. Politician and finance man. Leader of the Catalan liberal monarchists. Between September 1924 and February 1930, he served as mayor of Barcelona and during his term of office the Diagonal avenue was extended to Esplugas de Llobregat, the Plaza de Cataluña was urbanized, the Balmes street railway was covered and the Great Metro of Barcelona was built. He began the first campaign to eradicate shanties. He was also responsible for the organization of the Universal Exhibition of 1929.

${ }^{3}$ Named in homage to Joaquín León Milans del Bosch and Carrió. Miguel Primo de Rivera appointed him civil governor of Barcelona (1924-1929). From this position he carried out an intense anti-Catalanist campaign. He closed the field of the Football Club Barcelona and the Catalan Orfeón (1925), prohibited hikers and cultural entities, suspended and fined newspapers
} 
During the Spanish War, Bon Pastor suffered the bombing of the Italian air forces (1937) on Sanchís factory (Chemistry) which caused, too, nine victims, including three children, among residents of the houses (fig. 2).

After the war the territory was annexed to Barcelona and, in the context of Francoist development period, it grew as an industrial (Industrial Estates) and massive worker housing territory.

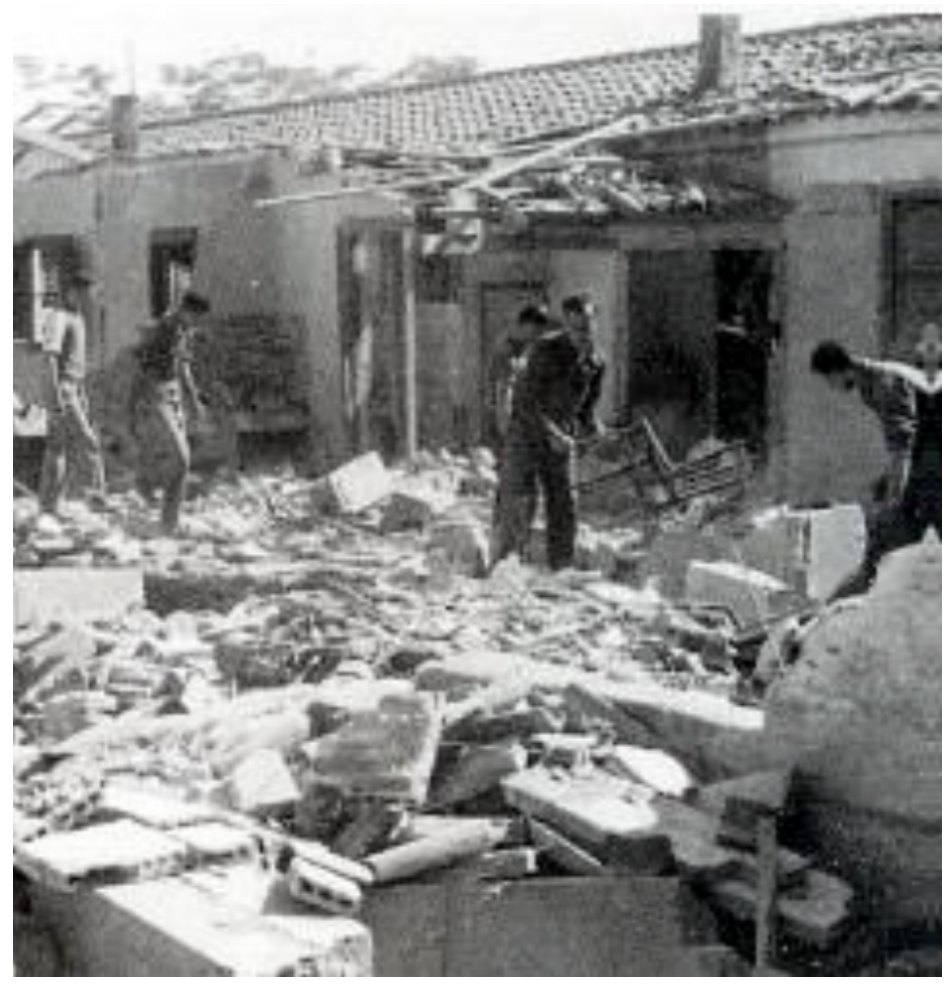

Fig. 2. Residents of Bon Pastor collecting the debris produced by the Italian bombing, 1937.

Source: Archive "Fem la Memoria del Bon Pastor" [Projecte de participació ciutadana al Barri de Bon Pastor (Barcelona), realised by L'associació de Veïns i Veïnes de Bon Pastor and Centre de Recerca Polis: Art Ciutat, Societat (CR Polis) de la Universitat de Barcelona, 2014-2015].

and magazines. After the fall of the dictator he was dismissed, retiring to Madrid. During the Second Republic these neighbourhoods changed their names: Baró de Viver was renamed Pi i Margall and Milans del Bosch - Carles Aribau. See: Martí Checa and Carme Travé, Bon Pastor Història d'un barri (Barcelona: Ajuntament de Barcelona, Districte de Sant Andreu, 2007); Xavier Salas, L'artista com a facilitador en els processos de participació ciutadana: el cas Baró de Viver a Barcelona (Barcelona: Universitat de Barcelona, 2015); Xavier Salas, "Bon Pastor (Barcelona) un territorio en construcción.” On the w@terfront, vol. 43 (2016): 7-46. 
The growth of the neighbourhood under the Franco regime was based on the processes of:

- Spatial segregation: bad communications, isolation etc.

- Economic and social segregation: poverty, lack of facilities, stigmatization etc.
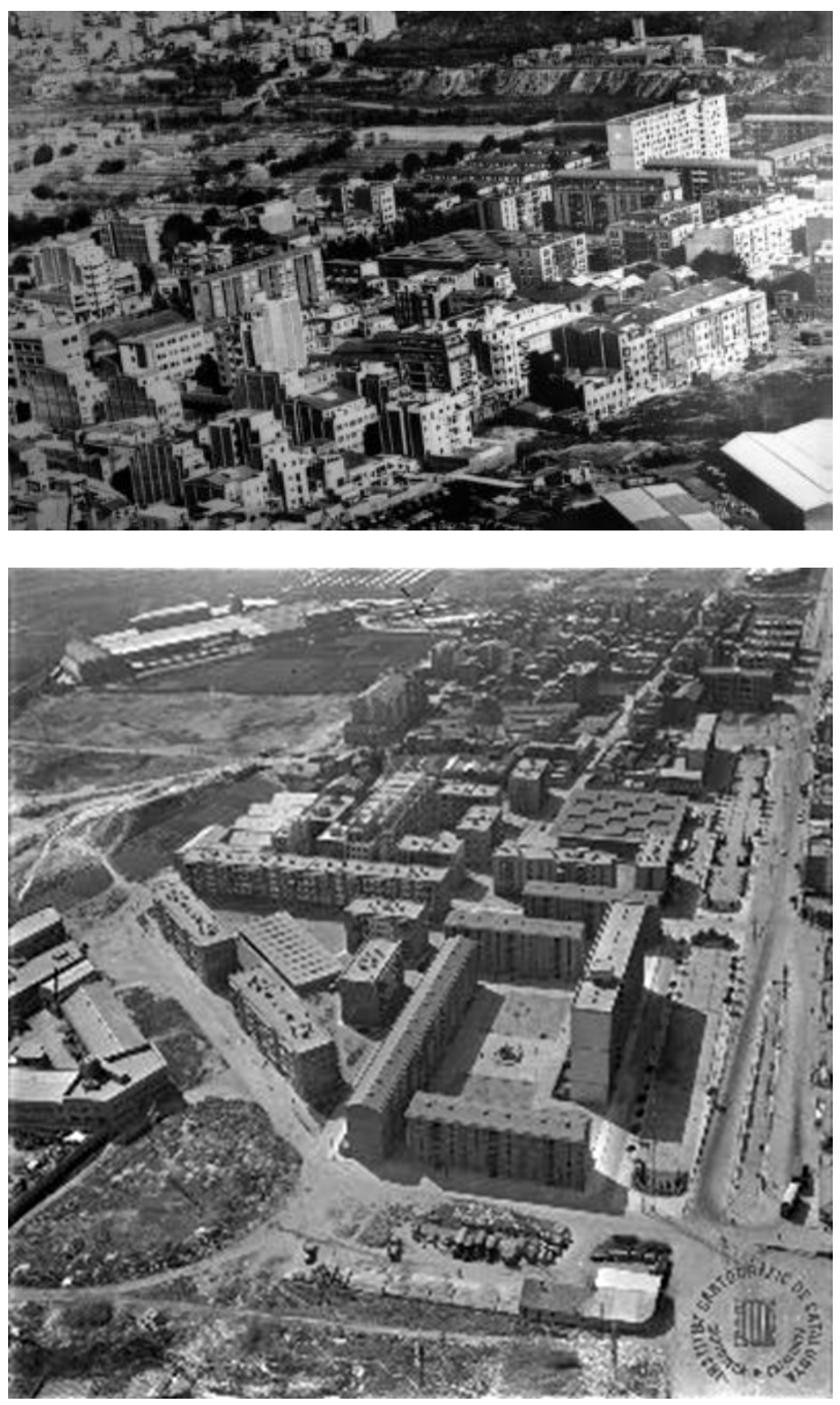

Fig. 3-4. Two views showing residential neighbourhood growth in the 1950 s to 1970 s.

Source: ICGC [Institut Cartogràfici Geològic de Catalunya]. 
The time of the Franco regime was the time of repression. The Church called apostolic "missions" to work in the district. Social assistance (creation of a dispensary in the rectory) and almsgiving made up for much of the services to which citizens were entitled. Nevertheless, Bon Pastor remained a united neighbourhood in the face of deficits and adversities: a struggling and united neighbourhood that went out to claim the "absences" of public investment in health (a struggle for the Health Centre in the middle of 70's), education (a struggle for a professional school in recent years), transportation (a struggle for the metro and for improvement of the bus lines arriving to the area at the end of the $20^{\text {th }}$ century), and public space (since the Olympics in 1992). They also fought for a culturally active neighbourhood supportive to the less favoured (fig. 5, 6).
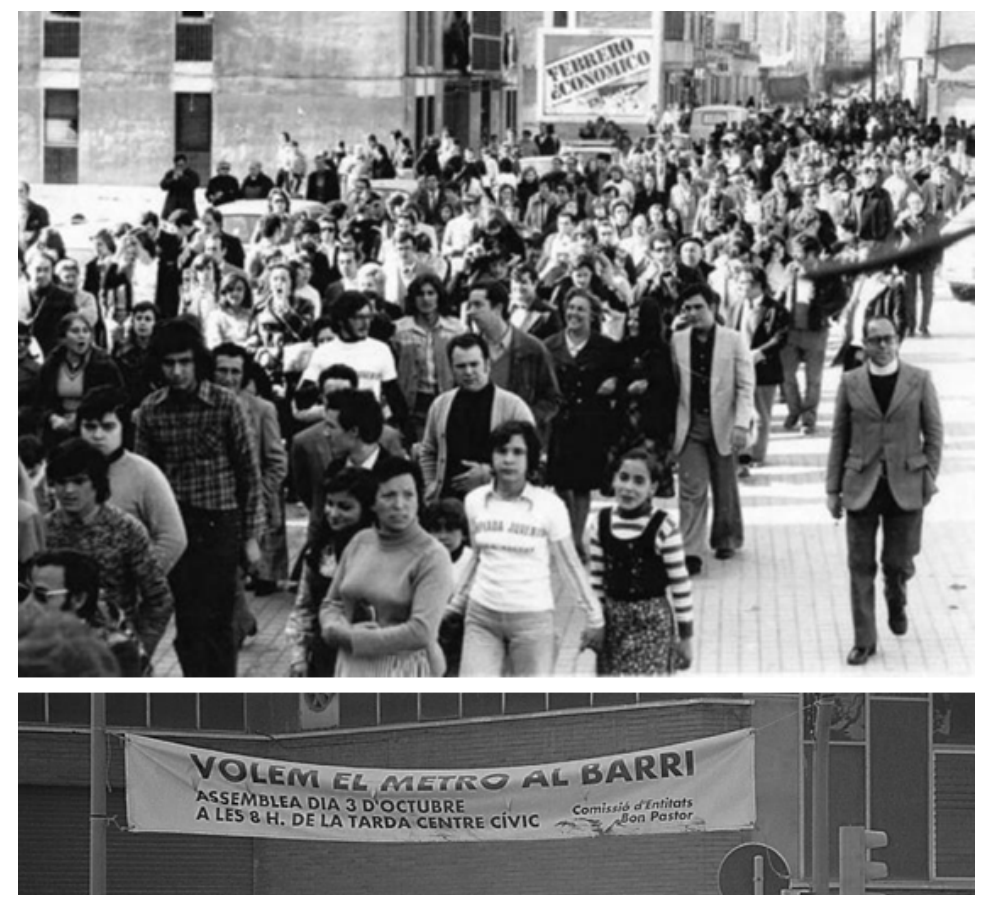

Fig. 5-6. Above. Demonstration of neighbours to claim a health centre, 1974. Below. Banner on the occasion of the protests claiming the arrival of the subway to Bon Pastor, 1986.

Source: Fem la Memoria del Bon Pastor.

\section{TOWARDS THE DISAPPEARANCE OF LOW-INCOME HOUSES ("THE CHEAP HOUSES")}

The 1953 Regional Plan introduced the industrial, residential and infrastructure growth and development of the territory. But, also, the "Partial Plan for remodelling the housing group Milans del Bosch," approved in December 1968 
and modified in 1971, approved in December 1968 and modified in 1971, envisaged the disappearance of the horizontal city model represented by the group of low-income affordable houses (fig. 7).

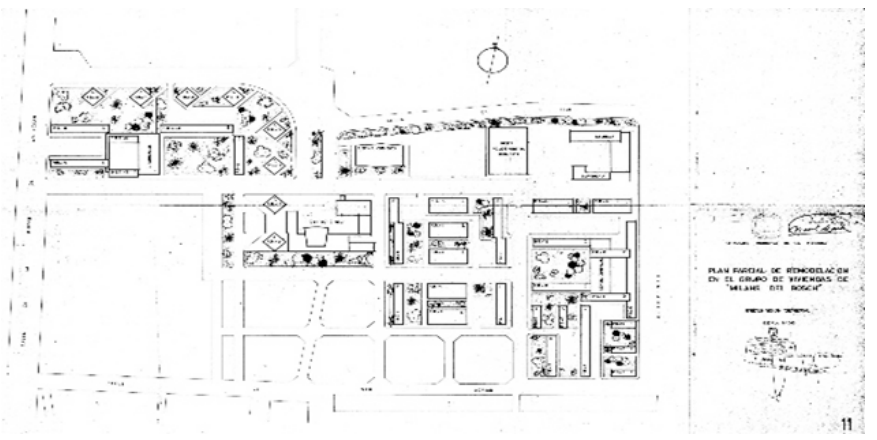

Fig. 7. "Partial Plan for remodelling the housing group Milans del Bosch," approved on $17^{\text {th }}$ December 1968 and modified in 1971. Source: Arxiu Municipal administratiu de Barcelona.

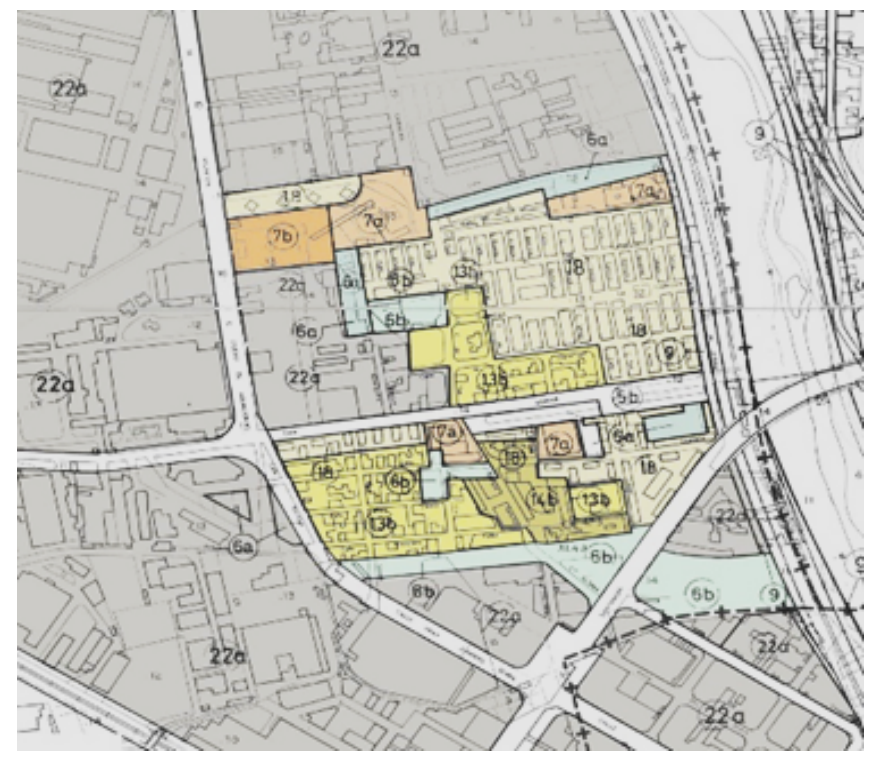

Fig. 8. Area scheme of the urban qualifications in the 1976, PGM [Metropolitan General Plan].

Source: Registre de Planejament Urbanístic de Barcelona.

The 1976 PGM (General Metropolitan Plan) went further in this direction, by qualifying the territory with the code 18 , which meant zone subject to volumetric ordination (fig. 8). However, as a result of neighbours' pressure, the 1985 PERI proposal (Special Reform Plan) for the Bon Pastor, was introduced. It assumed the rehabilitation of the group of houses (for a total of 333 houses 80 
were rebuilt) through raising their height and increasing the habitable surface from 48 to 70 sq. m. (project by architects Lluís Alegre and Jaume Barnada (fig. 9), as well as improving the public space and urban infrastructure. At the same time, the PERI considered the replacement of the remaining 451 houses with medium density blocks.

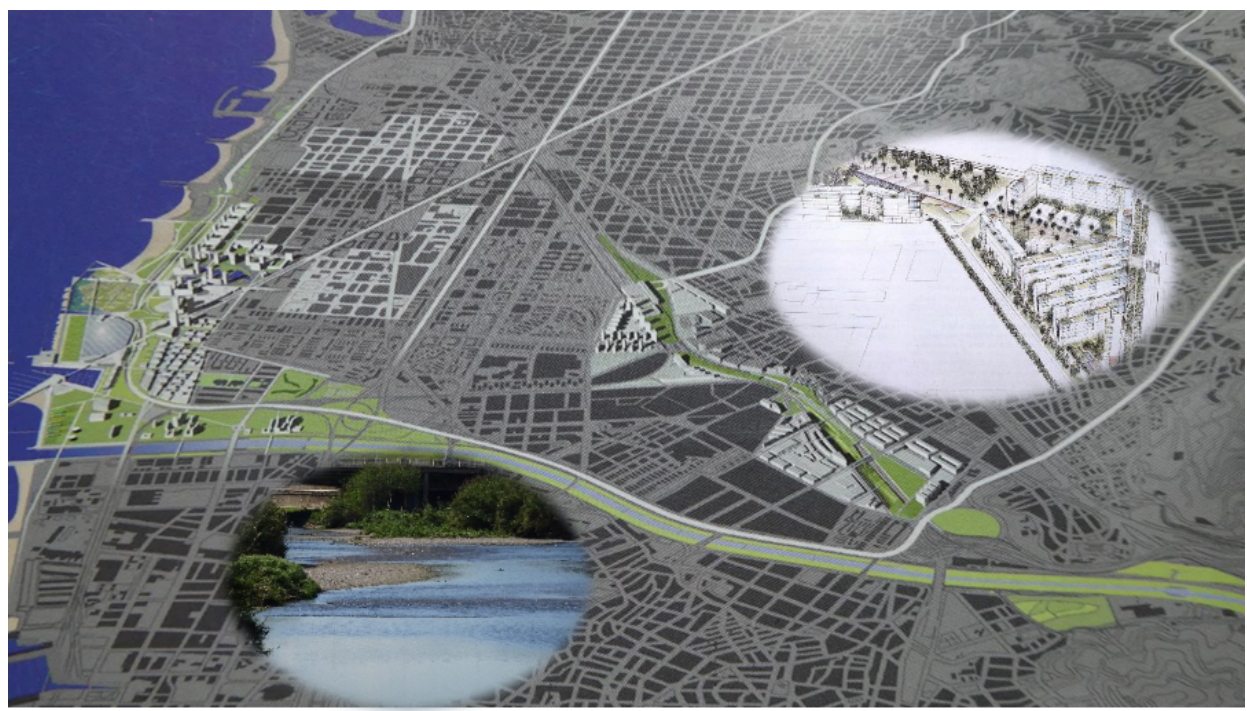

Fig. 9. The so-called New Projects. Recovery of the Besòs River, development of the shoreline, HST corridor in La Sagrera wit the "Maquisnista" commercial and residential development plan. Source: Barcelona Regional.

This project was based on economic aid from the Spanish central government. In 1988 the central government stopped giving aid for the rehabilitation. Therefore, the Municipal Housing Board reformulated the plan, allowing the demolition of the houses and their replacement by housing blocks while creating a Commission to monitor the affected neighbours.

In 1998, the Municipal Housing Board (PMH) drafted the document "Criteria, Objectives and General Planning Solutions in the Bon Pastor Housing Estate," which was finally approved on April 28, 1999.

At this moment (1999) it is also proposed:

- the recovery of the Besòs river,

- the project of La Maquinista Mall and a newly built neighbourhood within the limits of Bon Pastor, and

- the Sagrera project linked to the HST.

Within this framework, the negotiations between neighbours and City Council were also started in order to reshape the neighbourhood territory. 


\section{2000 - BON PASTOR. A NEIGHBOURHOOD WITH FUTURE}

In the year 2000, the Association of neighbours presented the document "Bon Pastor. A neighbourhood with a future" (fig. 10).

This would be the strategic document that will allow the development of a series of actions to conduct the physical remodelling of the neighbourhood and definitively enable the replacement of houses by new housing blocks. The principal aims of the proposal were:

- To promote the Bon Pastor as an open, plural and inclusive neighbourhood, linked to the district and city global project.

- No renouncing to its marked community personality, socially active and cohesive, and committed to educational quality.

- An intercultural and solidary neighbourhood, which maintains a balance between urban growth and productive activity and defends its commitment to the quality of its natural environment.

The Plan for the Future chose the model of sustainable and balanced development for Bon Pastor. In 2000-2001, we attended to the presentation of the open ideas competition. The winning project, definitively approved in 2003 (architect Jordi Romero Sabí), offered a modification of the PGM (Metropolitan General Plan). This project was in many respects appreciated by the neighbours, but it also received, on the part of the neighbourhood organizations, a series of important qualifications (see fig. 11-16). They claimed their reservations concerning both constructive aspects, and the questions of management of the relocation process, related to the replacement of the small houses with apartments blocks. The neighbours' qualifications were:

- Brick-built buildings,

- Kitchens as fully equipped as possible,

- Green areas around all blocks and buildings without porches,

- Completed phase, urbanized phase,

- Expenses for contracting supplies by the Municipal Board of Housing (electricity, water, ...),

- Moving to new homes, also in charge of the Board,

- Subsidies of $30 \%$ of the cost price to those family units that earn less than 2.5 the minimum interprofessional salary. Subsidies of up to $15 \%$ to family units that earn between 2.5 and 3.5 times the minimum interprofessional salary. Commitment on the part of the Generalitat that, based on the census that the Board will carry out, it will increase the aid within the section from 2.5 to 3.5 ,

- Life annuity as low as possible (10\% of incomes for elders 65$)$,

- Affordable rents,

- Priority over the remaining floors for those born in the neighbourhood,

- No to speculation in the plots occupied by the 784 houses. 

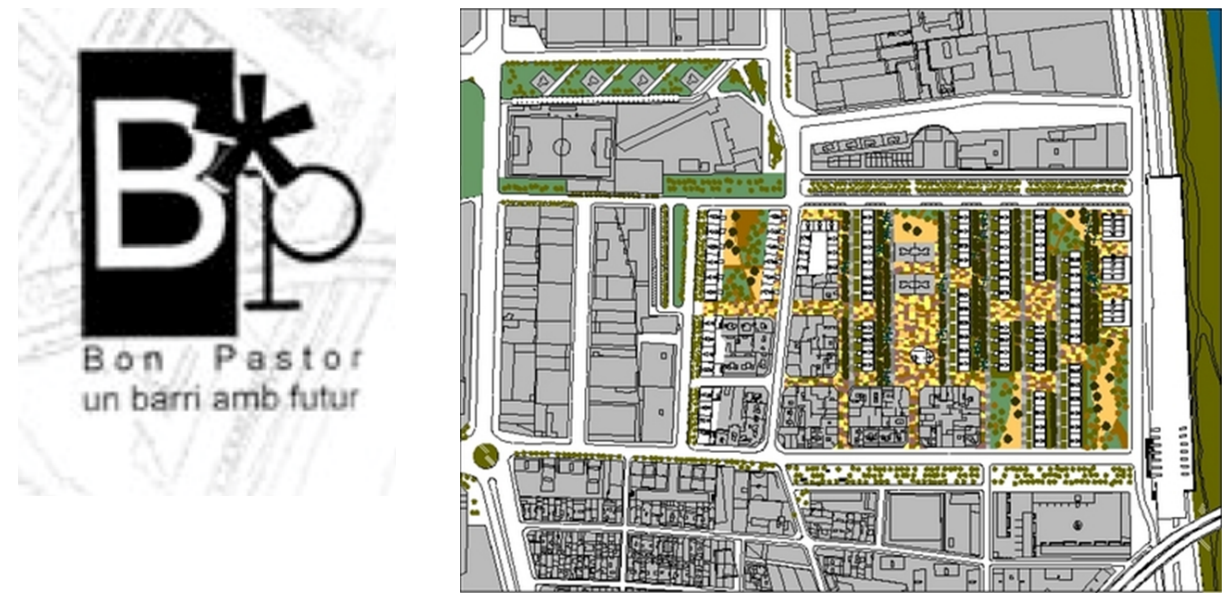

Fig. 10. Cover of the document "Bon Pastor, a neighbourhood with a future."

Source: Archive of the Associació de Veïns i Veïnes del Bon Pastor.
Fig. 11. Presentation of the open ideas competition winning project modifying the PGM (Metropolitan General Plan). Definitively approved in 2003 (architect Jordi Romero Sabí).

Source: Registre de Planejament Urbanístic de Barcelona.

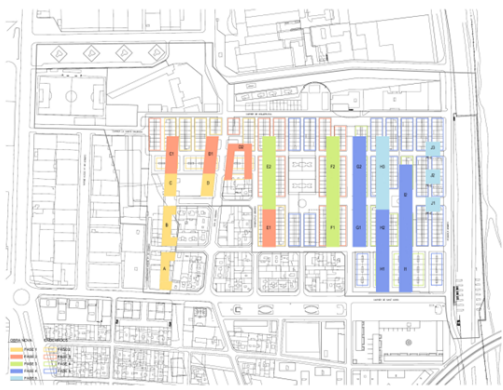

Plan for the five rehousing stages

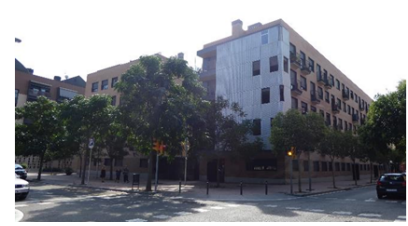

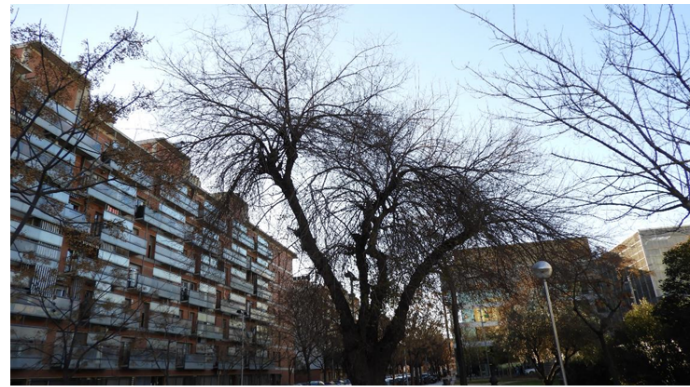

Built blocs in stages 1 to 3
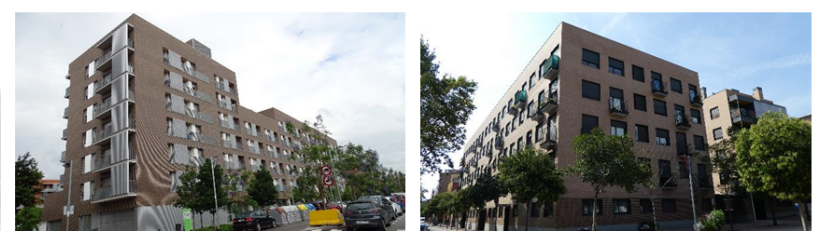

Fig. 12-16. Plan of the different relocation phases. Source: Registre de Planejament Urbanístic de Barcelona. New housing blocks built in the relocation plan.

However, the process has not been peaceful. In the same year 2003, a new association was created, AVIS, which has revealed to be contrary to the process (see fig. 17, 18). From 2004 to 2015, there was developed the project called 
"The horizontal city" driven by the University of Barcelona. ${ }^{4}$ The retort to the neighbours and City Council project is internationalized through an international contest of ideas but that has had only has a limited impact on local public opinion.

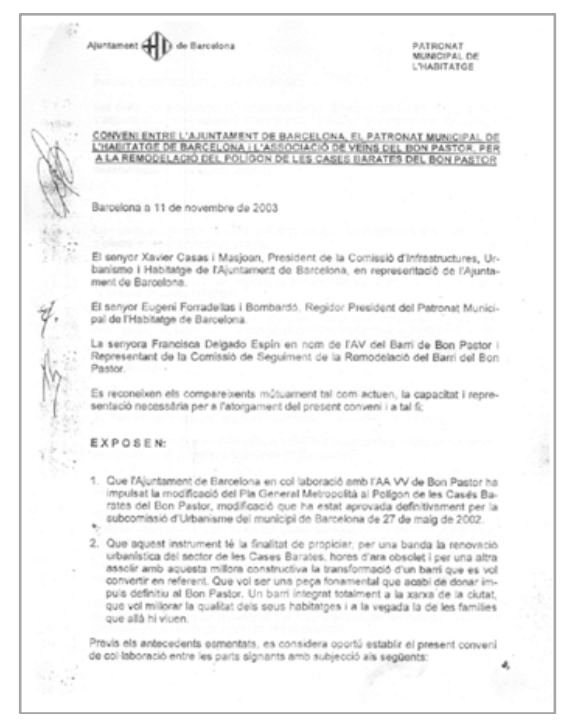

Fig. 17. Agreement between the City Council of Barcelona, the Municipal Housing Board, the Bon Pastor Neighbourhood Association for remodelling of the Bon Pastor estate, 2003.

Source: Archive of the Associació de Veïns i Veïnes del Bon Pastor.

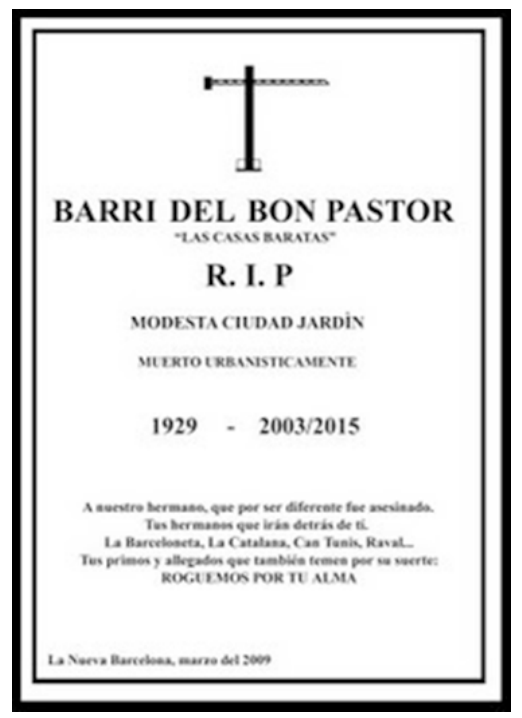

Fig. 18. One of the protest posters against the residential renovation process, 2015.

Source: Archive of the Associació de Veïns i Veïnes del Bon Pastor.

\section{2010 - ACCESIBILITY - THE METRO}

The 1971 Metro plan envisaged three stops of the so-called IV line in the area of Bon Pastor, closely linked to the industrial estates. In the early 1980s the investment agreement between the City Council and the Generalitat failed

\footnotetext{
${ }^{4}$ This resistance process to the relocation plan was reported by: Stefano Portelli, La ciudad horizontal. Urbanismo y resistencia en un barrio de casas baratas de Barcelona (Barcelona: Ed. Bellaterra, 2015); Stefano Portelli, La ciutat horitzontal. Urbanisme i resistència en un barri de cases barates de Barcelona (Barcelona: Generalitat de Catalunya, 2015); A.V.I.S del barri [blog], http://avisbarri.wixsite.com/avis-del-barri; Emanuela Bove and Isabel Cadenas, Joan Escofet, Claire Galleyrand, Martha Pelayo, Eva Palaudàries, Stefano Portelli, Claudia Villazon, Volker Zimmermann, Un experimento de reflexión colectiva para una periferia urbana: el Concursode ideas Repensar Bonpastor, entre arquitectura y antropología (2009-2010) (Barcelona: Perifèries Urbanes/Grup de treball de l'Institut Català d'Antropologia, 2010), http://periferiesurbanes.org/wp -content/uploads/2010/08/Repensar-2010-ESP.pdf; Repensar Bonpastor. Para una remodelación participativa y con cero desalojos de un barrio popular de Barcelona [blog], https://repensar bonpastor.wordpress.com/; Repensar Bon Pastor, https://vimeo.com/7318712
} 
to accord to extend the subway to Bon Pastor. Finally, the neighbours' pressure allowed the inclusion of the Bon Pastor metro station in the Infrastructure Master Plan 2001-2010 (cf. fig. 19, 20). In 2010 the Bon Pastor metro station was opened.

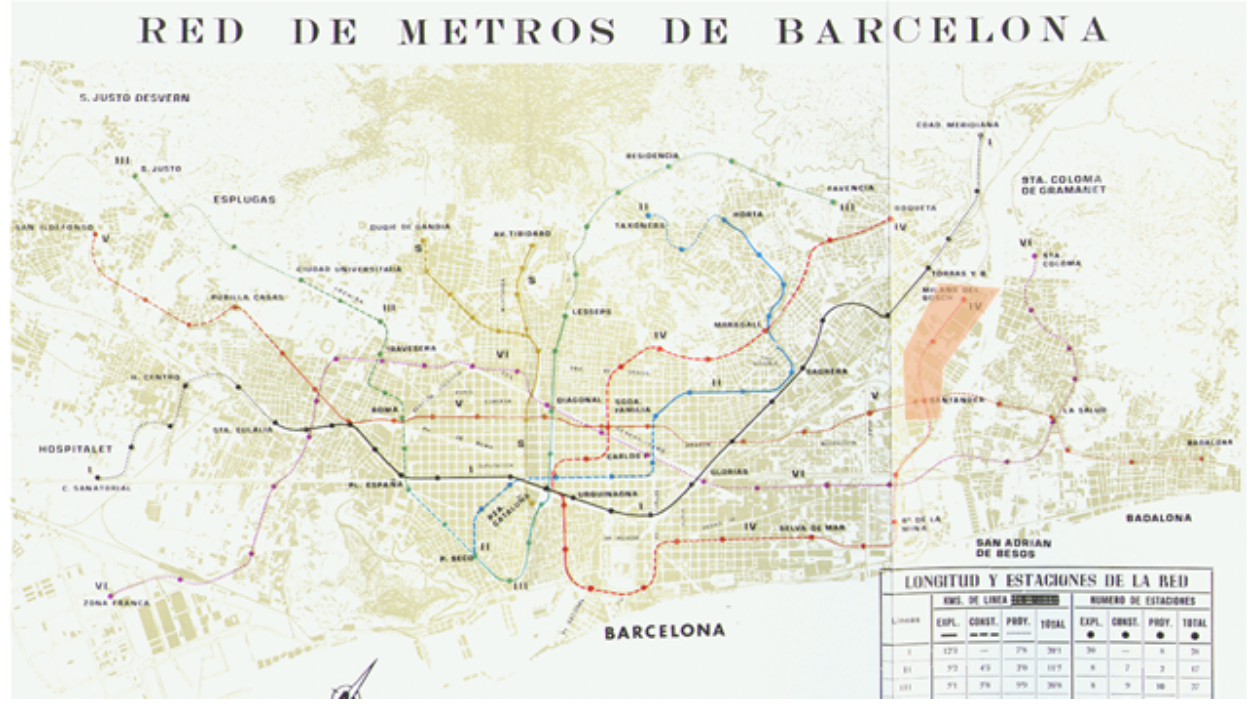

Fig. 19. Metro Plan for Barcelona (1971), which envisaged two stops of Line IV in the area of Bon Pastor. Source: ICGC [Institut Cartogràfic i Geològic de Catalunya].

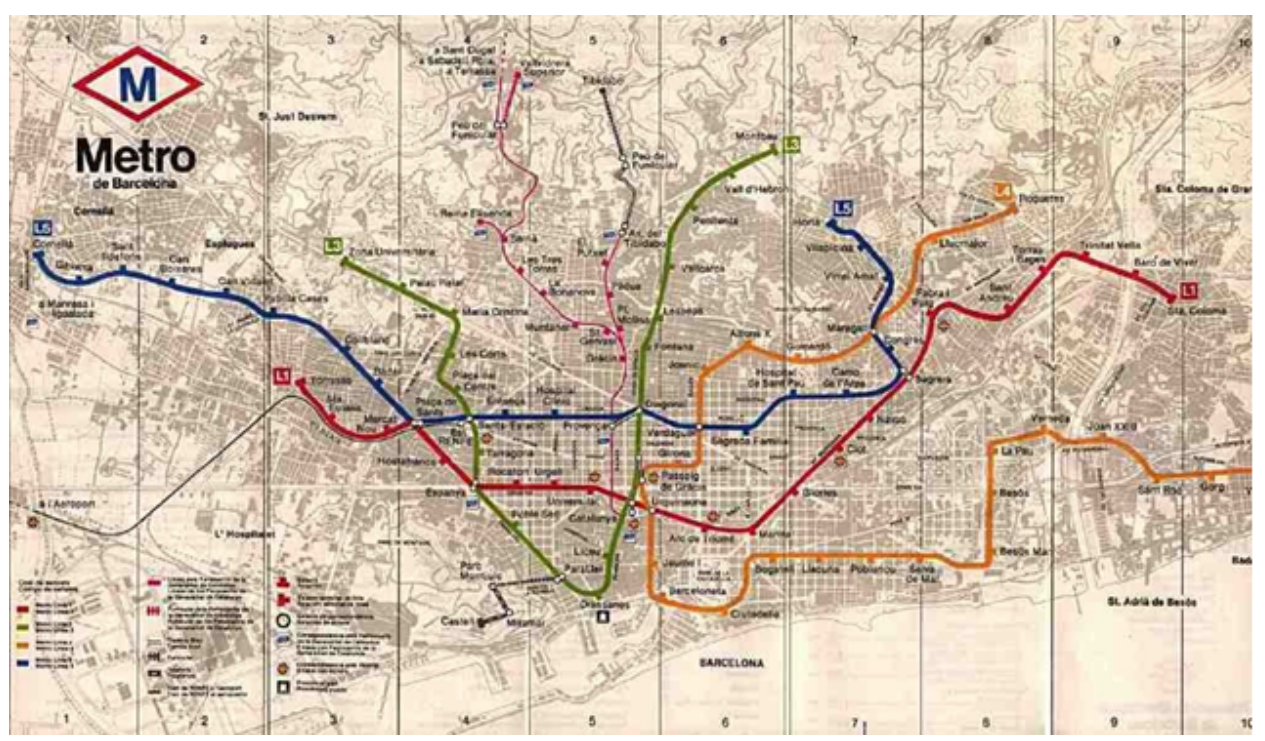

Fig. 20. New Metro plan of the early 1980s in which these stations disappear.

Source: ICGC [Institut Cartogràfic i Geològic de Catalunya]. 


\section{FROM NEIGHBOURHOODS ACT (2009) TO NEIGHBOURHOOD PLAN (2016)}

In 2004, the Generalitat de Catalunya enacted the Neighbourhoods Act, as an instrument "to improve neighbourhoods, urban areas and towns that require special attention." In the 2009 call for projects, the City Council presented the integral project for the Bon Pastor-Baró de Viver that, initially, received a subsidy of $€ 8.6$ million. However, with the nationalist government and the beginning of the cuts, this subsidy was compromised, and the City Council deployed its own project for neighbourhoods at social risk. In this context, following an idea of neighbourhood-organizations, the City proposed to preserve a row of houses to turn them into a "museum space of popular housing." An Urban Improvement Plan (PMU, 2011) was then drawn up considering this new reality (fig. 21).

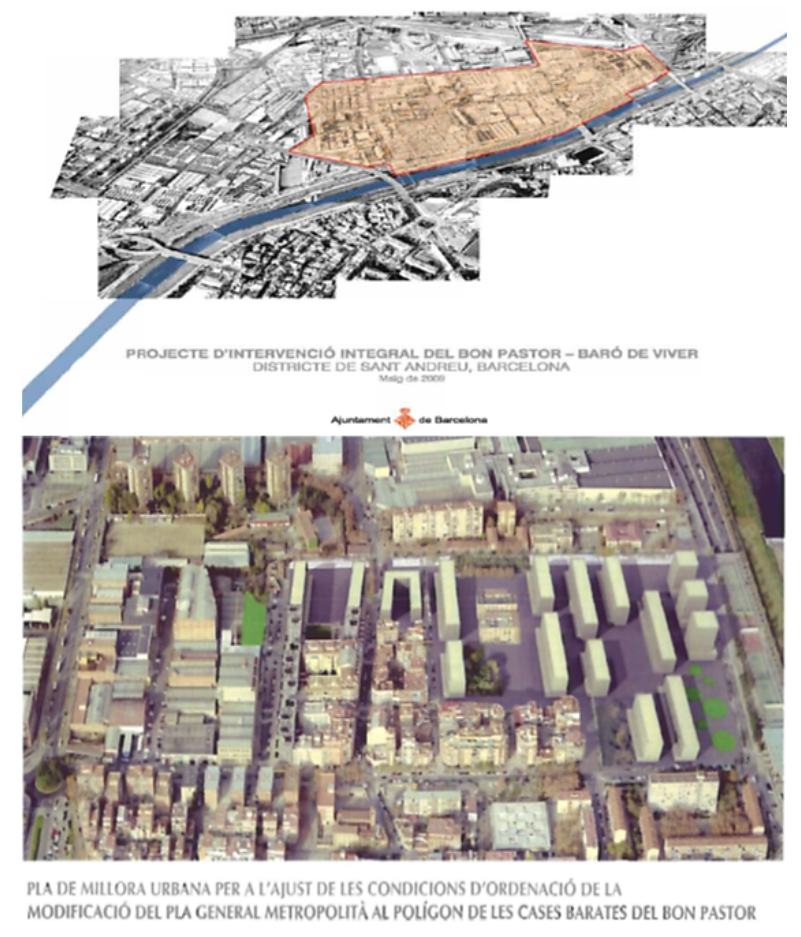

Fig. 21. Document of the District of Sant Andreu. Candidacy to the call of the Neighbourhoods Law by Generalitat de Catalunya, 2009.

Source: Archive of the Associació de Veïns i Veïnes del Bon Pastor.

\section{THE REMEMBRANCE PROJECT}

In this context, the Association of neighbours started a double working process about the social and historical remembrance. On the one hand, it began to work with the Museum of History of the City (MUHBA) on the project of the local 
exhibition space. On the other hand, it entered into cooperation with CR POLIS regarding the implementation of the project "Building Bon Pastor's Remembrance." The cooperation with this academic center started with the "Remembrance Mural" experience, which resulted from a citizen participation process in the neighbouring district of Baró de $\operatorname{Viver}^{5}$ (2011, fig. 28).
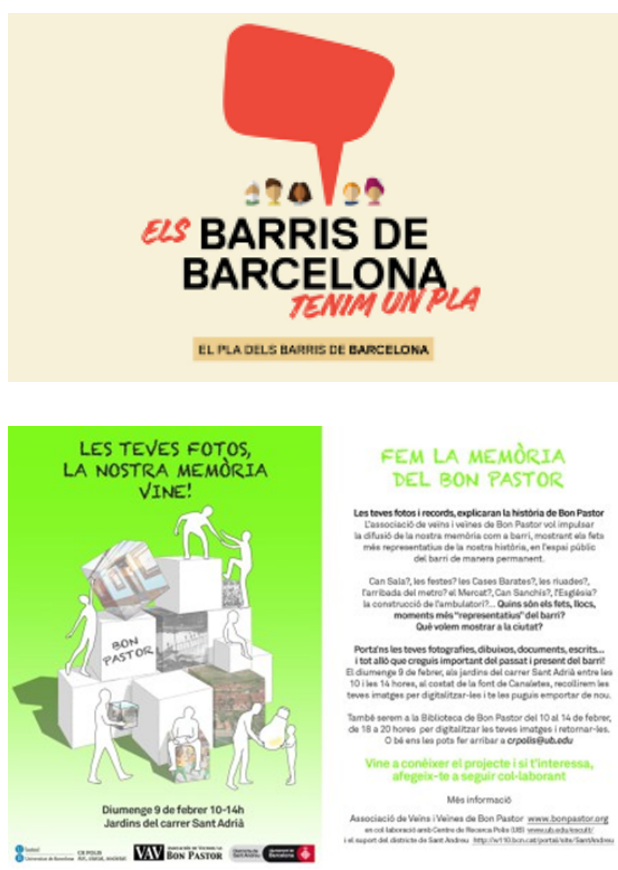

Fig. 23. One of the first posters of the project "Let's do the Memory of Bon Pastor."

Source: CR POLIS.
Fig. 22. Left. One of the consequences of the economic crisis of 2007 was the suspension of funding for the actions of the Neighbourhood Act. In 2016, the government of Barcelona launched a substitute plan, the Barris Plan, to alleviate the lack of investment on the part of the Generalitat. All the neighbourhoods on the banks of the Besòs, Bon Pastor included, have benefited from this new plan. Source: CR POLIS.

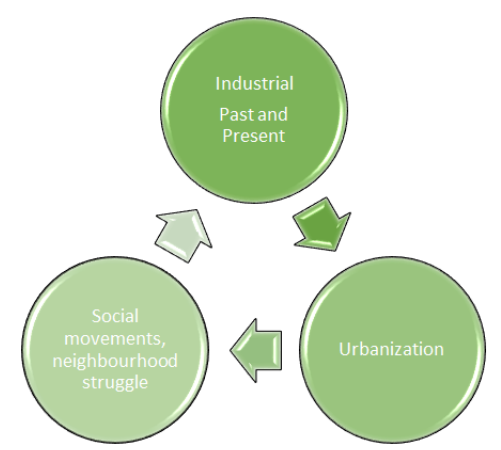

Fig. 24. The three pillars in the participatory process on the "civic remembrance" of Bon Pastor.

Source: CR POLIS.

\footnotetext{
${ }^{5}$ For further literature on the Mural of the Remembrance in Baró de Viver, see: Antoni Remesar and Bibiana Crespo, "El sistema espacial de Memòria cívica al barri de Bon Pastor (Barcelona). Estudi del Centre Blanco," On the w@terfront, no. 60/4 (2018): 3-51; Antoni Remesar and Bibiana Crespo, "The White Centre. A first step of the civic remembrance system in Bon Pastor (Barcelona)," Acta Universitatis Lodziensis. Folia Philosophica. Ethica - Aesthetica - Practica, no. 30 (2017): 9-39; Antoni Remesar and, Xavier Salas,Tomeu Vidal, Bibiana Crespo, Roser Masip, Cohesión urbana. Construyendo la memoria. Baró de Viver - Bon Pastor. Dos exposiciones (Barcelona: CR POLIS/Universitat de Barcelona, 2016); Porta la teva foto el Bari. La pantalla la construïm tots junts. Album de fotos Baró de Viver (Barcelona: L'Associació de Veïns i Veïnes Pi i Margall de Baró de Viver, 2010), http://www.ub.edu/escult/baro/folletos_difusion/2010/IV\% 20JORNADAS/4_jornadas_particip ativas.pdf; Carme Grandas, "Comentari. Mural de la Memoria de Baró de Viver," 2011, www.bcn.cat/artpublic; Xavier Salas, L'artista com a facilitador en els processos de participació ciutadana: el cas Baró de Viver a Barcelona (Barcelona: Universitat de Barcelona, 2015).
} 
At the end of 2013, the Bon Pastor Neighbourhood Association contacted the POLIS Research Center, with the intention of developing a project similar to the one carried out two years earlier in Baró de Viver. The project of the "Civic Memory" of Bon Pastor started at the beginning of 2014 with some resistance from the district administration - at that time in the hands of the right-wing nationalists (CIU). The effect of the City Council Neighbourhood Plan (2016) would facilitate the development and the confluence of both projects. In 2015, CR POLIS, the district of Sant Andreu and the Neighbourhood Association signed a cooperation agreement for the development of a participatory project on the implementation of the Historical Memory of the neighbourhood in the public space (fig. 23). This created a triple structure of work on Memory, where neighbours played a central role in coordinating the initiatives with Pla de Barris (fig. 22), MUHBA and CR POLIS. The series of participatory workshops reached the conclusion that the translation into the public space of the Remembrance project of the neighbourhood could not reproduce the linear scheme based on images that had been used in Baró de Viver.

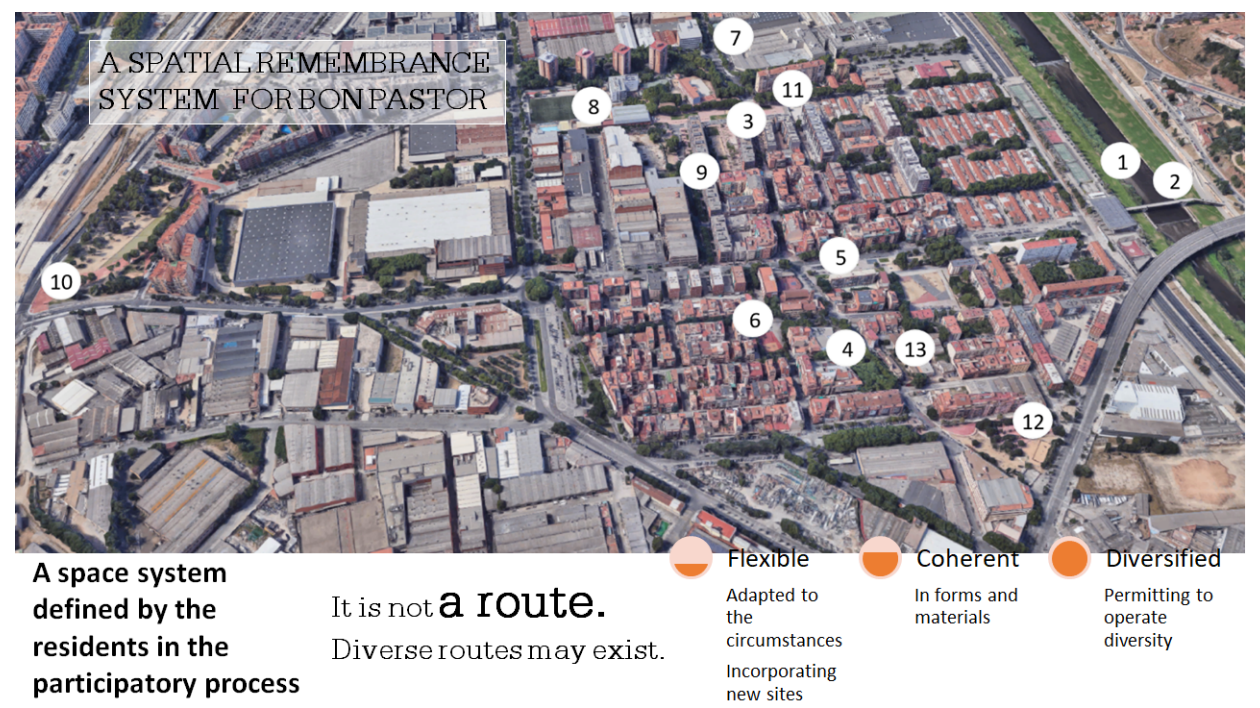

Fig. 25. Map of the different points of the territory that should receive the physical "marking." Source: CR POLIS.

The different points of the Remembrance Space System have been analyzed regarding the three dimensions expressed in the image 24 . The decision was made to create a spatial remembrance system that would enhance certain points of the territory with socially significant value (fig. 25). Starting from this premise, the "laboratory of ideas" of the M.A: in Urban Design, developed some proposals focused on the deployment of "spatial marks" on the ground, trying to avoid the multiplication of vertical signs in public space (fig. 26). 
The site is marked with an intervention on the pavement, using the most widespread paving system in Barcelona since the beginning of the $20^{\text {th }}$ century: the so-called "panots:" pieces of $20 \times 20 \times 5 \mathrm{~cm}$ of hydraulic concrete with different forms (fig. 29, 30).

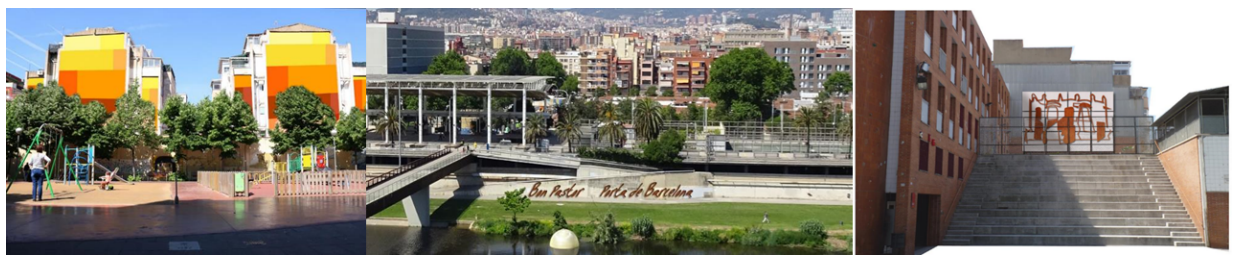

Fig. 26-28. Parallel to the general system, the treatment of "relevant points" with public art interventions is considered. A plan for landscape integration of the vertical plane is also proposed. Source: CR POLIS.
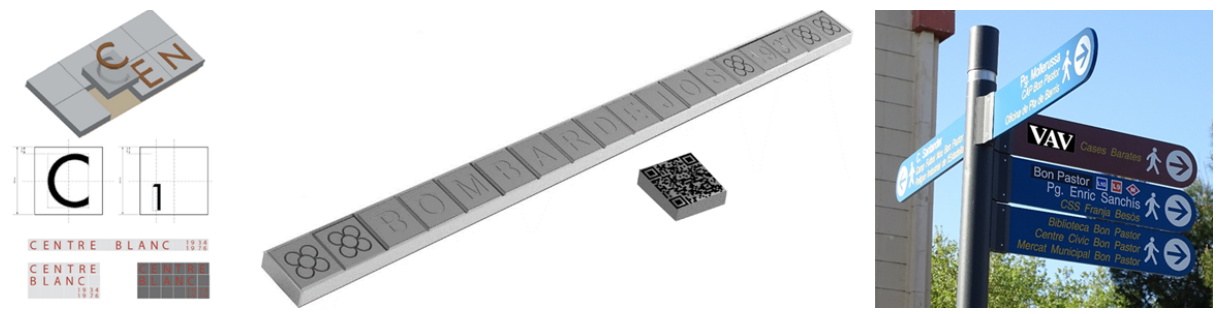

Fig. 29. Progress of ideas on the use of pavement "panot" as a fundamental element of the deployment of spatial remembrance system. Marking the ground correlates with the urban signaling system and with a web system in which the contents (augmented reality) of each of the marked points would be developed.

Source: CR POLIS.

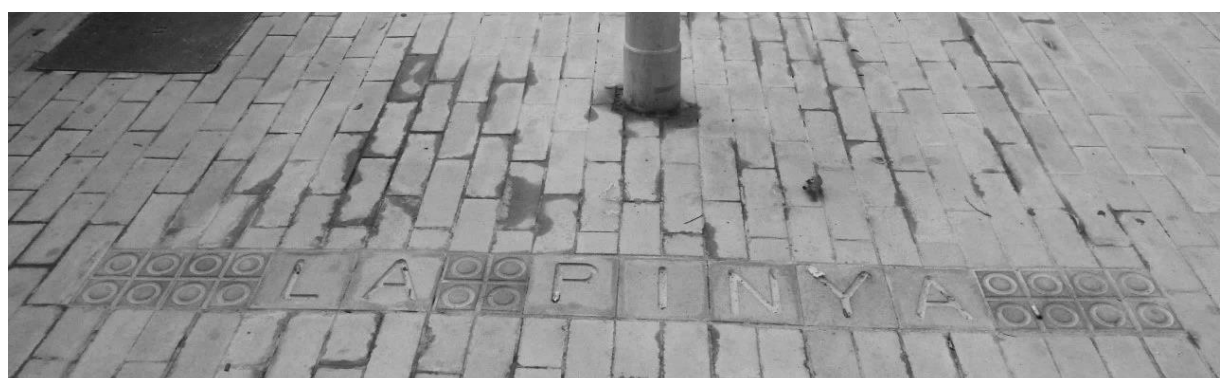

Fig. 30. Panots - the first intervention of the 13 planned.

Source: CR POLIS.

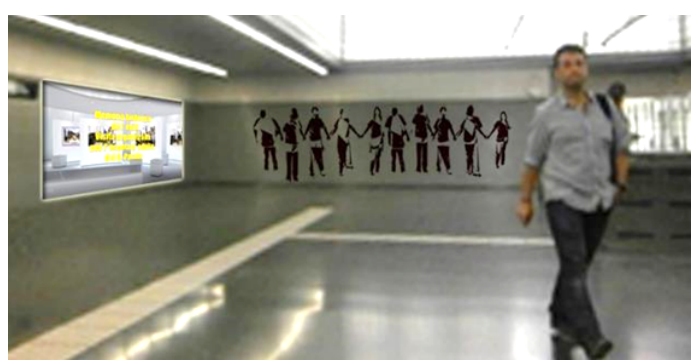

Fig. 31. The proposal of a large audiovisual display in the hall of the metro stop, which would establish the connection between the space system of memory and the implementation of the museum space of the Cheap Houses.

Source: CR POLIS. 
These indications on the ground have the complement in the local signalling system. In addition, they can incorporate elements such as "QR," or similar, to make it possible to provide augmented reality data via mobile phone. We propose to develop a contest among neighbourhood schools students to get an identity "marque" to incorporate into the neighbourhood signalling system (fig. 32).

In some places of special significance for the neighbourhood, it is planned to incorporate: public art works; visual improvement of the landscape and a proposal for a colour plan (especially on the party walls); even, welcome marks to the neighbourhood, as it can happen in the embankment of the Besòs river.

A particularly significant point is the location of a "museum space," in the rows of houses that will be kept, within the framework of the museographic project of the MUHBA (Museum of History of Barcelona). The urbanization of the environment at the site has created a plaza surrounded by greenery. In the square will be a monument to the nine victims of the bombing of Italian aircrafts in 1937. A monument combining water and light - a subtle monument remembering those who died under fascist bombs. The monument is under study.

A part of the "museum" space will be devoted to reproducing the physical environment (furniture, household goods, etc.). Another to a permanent exhibition about popular and working-class housing in Barcelona (fig. 33, 34). In addition, a conference room. The neighbours, like proponents and users of the facility, demand to manage an archive on the popular and working class housing. This archive would produce the web content to virtually expand the information available on the site, including the information gathered through participatory process. The archive should manage the contents of an information system in the metro station hall consisting of large screens emitting different types of contents; yet a subject to be negotiated with TMB, the municipal public transport company of Barcelona.

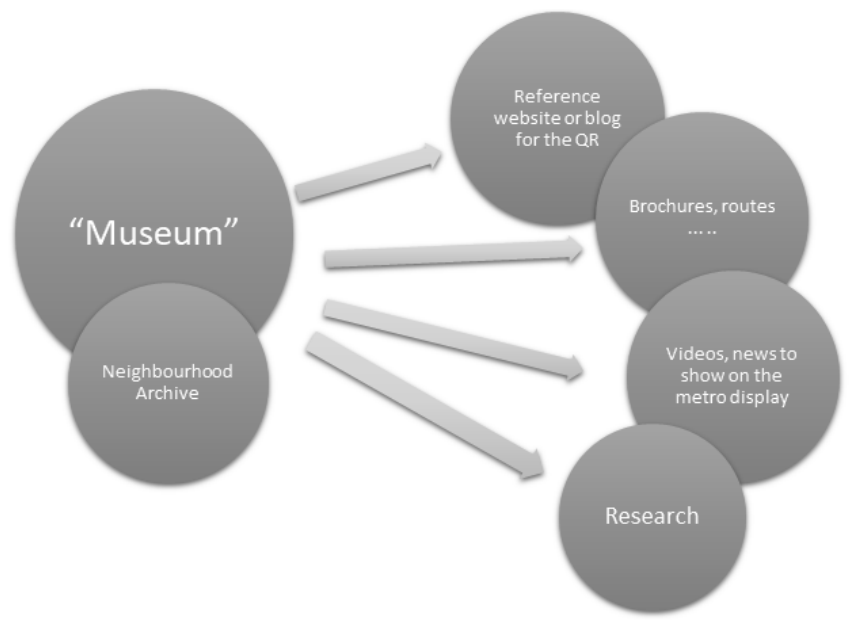

Fig. 32. Outline of the functions of the future museum space regarding memory processes developed in the neighbourhood.

Source: CR POLIS. 


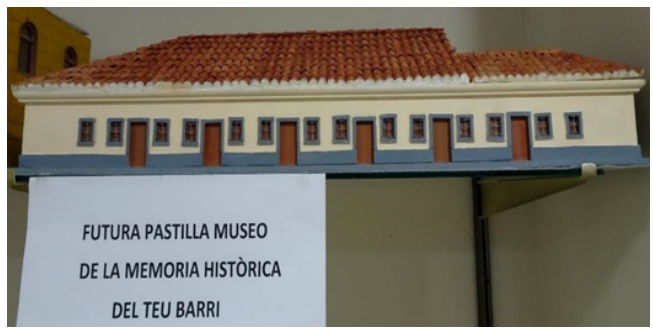

Fig. 33. Model of the block of cheap houses reserved for the museum space.

Source: CR POLIS.
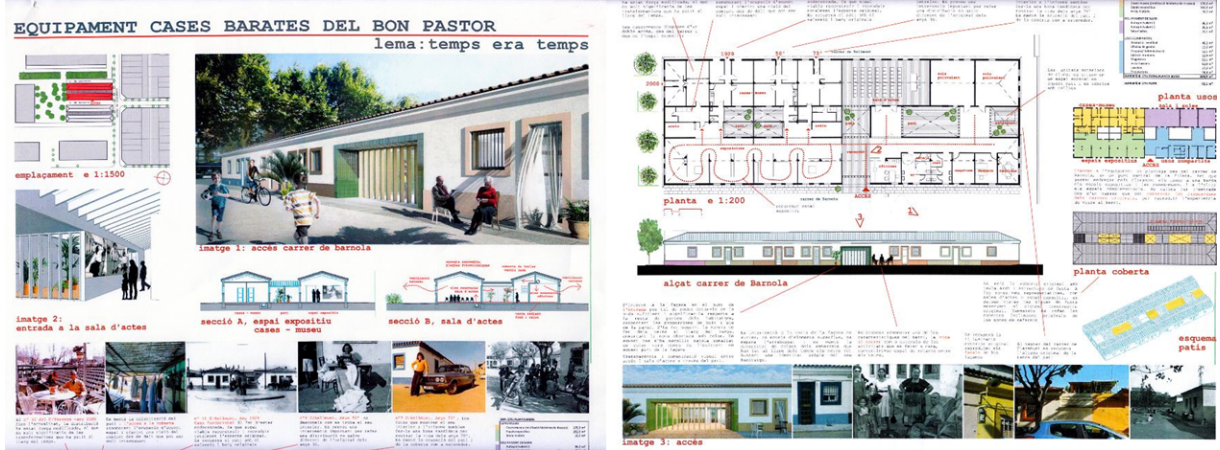

Fig. 34. Project for the new museum space. Aurora Fenández, Ricard Mercadé, Andrea Manent, architects. 2017.

Source: CR POLIS.

At the other end of the neighbourhood, in the old grounds of La Maquinista, there is, since 2000, a small exhibition space on the industrial remembrance of Barcelona (fig. 35). It is the Historical and Social Museum of the Maquinista Terrestre y Marítima (MTM) and MACOSA, managed by a Foundation of the same name of which former workers of these two large companies are part.

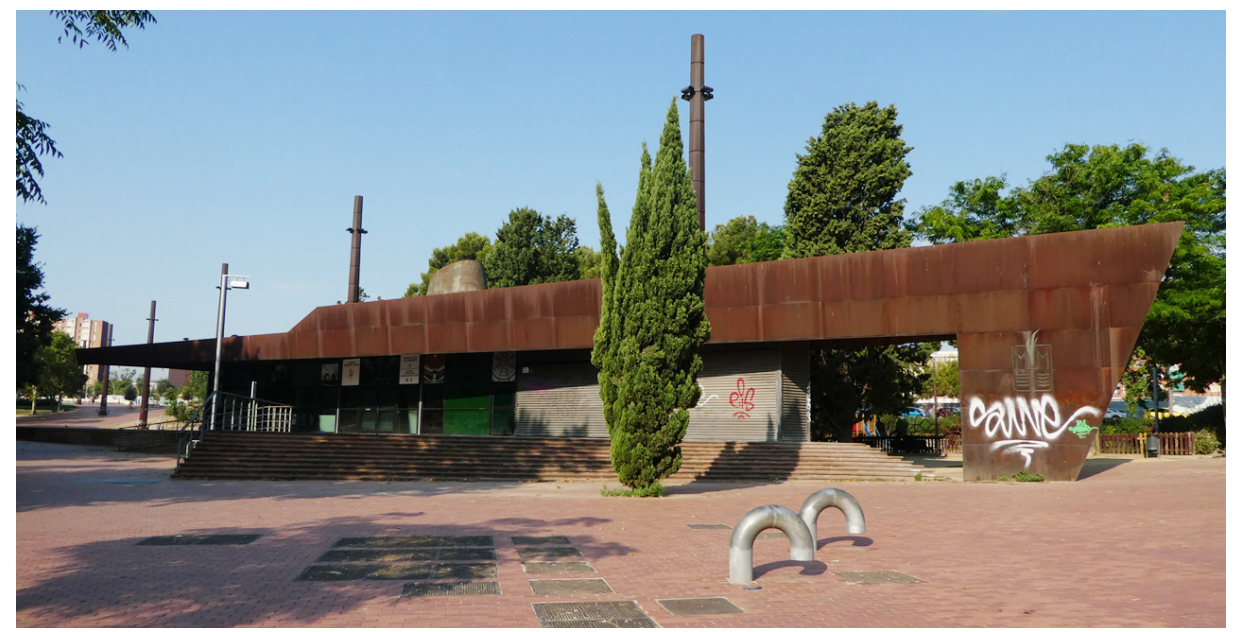

Fig. 35. Museum of the Maquinista Terrestre y Marítima (MTM) and MACOSA.

Source: CR POLIS. 
We hope that, with the planned actions, this museum space will be reactivated in such a way that, Bon Pastor, will bring together the manifestation of the industrial and residential remembrance of the working and popular classes.

The involvement of the neighbours and their active participation in developing and monitoring the relocation process, as well as their fight to rescue the civic, historic and workers remembrance, linked to the territory, can achieve, as it was stated in the year 2000, the Bon Pastor to be a neighbourhood with a future.

\section{BIBLIOGRAPHY}

Bove, Emanuela and Isabel Cadenas, Joan Escofet, Claire Galleyrand, Martha Pelayo, Eva Palaudàries, Stefano Portelli, Claudia Villazon, Volker Zimmermann. Un experimento de reflexión colectiva para una periferia urbana: el Concursode ideas Repensar Bonpastor, entre arquitectura y antropología (2009-2010). Barcelona: Perifèries Urbanes/Grup de treball de l'Institut Català d'Antropologia, 2010. http://periferiesurbanes.org/wp-content/uploads/2010 /08/Repensar-2010-ESP.pdf

Checa, Martí and Carme Travé. Bon Pastor Història d'un barri. Barcelona: Ajuntament de Barcelona, Districte de Sant Andreu, 2007.

Grandas, Carme. "Comentari. Mural de la Memoria de Baró de Viver," 2011, www.bcn.cat/artpublic

Porta la teva foto el Bari. La pantalla la construïm tots junts. Album de fotos Baró de Viver. Barcelona: L'Associació de Veïns i Veïnes Pi i Margall de Baró de Viver, 2010. http://www.ub.edu/escult/baro/folletos_difusion/2010/IV\%20JORNADAS/4_jornadas_partici pativas.pdf

Portelli, Stefano. La ciudad horizontal. Urbanismo y resistencia en un barrio de casas baratas de Barcelona. Barcelona: Ed. Bellaterra, 2015.

- La ciutat horitzontal. Urbanisme i resistència en un barri de cases barates de Barcelona. Barcelona: Generalitat de Catalunya, 2015.

Remesar, Antoni and Bibiana Crespo. "El sistema espacial de Memòria cívica al barri de Bon Pastor (Barcelona). Estudi del Centre Blanco." On the w@terfront, no. 60/4 (2018): 3-51.

. "The White Centre. A first step of the civic remembrance system in Bon Pastor (Barcelona)." Acta Universitatis Lodziensis. Folia Philosophica. Ethica-Aesthetica - Practica, no. 30 (2017): 9-39.

Remesar, Antoni and Xavier Salas, Tomeu Vidal, Bibiana Crespo, Roser Masip. Cohesión urbana. Construyendo la memoria. Baró de Viver - Bon Pastor. Dos exposiciones. Barcelona: CR POLIS/Universitat de Barcelona, 2016.

Salas, Xavier. "Bon Pastor (Barcelona) un territorio en construcción.” On the w@terfront, vol. 43 (2016): 7-46.

- L'artista com a facilitador en els processos de participació ciutadana: el cas Baró de Viver a Barcelona. Barcelona: Universitat de Barcelona, 2015.

Website content

A.V.I.S del barri [blog], http://avisbarri.wixsite.com/avis-del-barri

Repensar Bon Pastor, https://vimeo.com/7318712

Repensar Bonpastor. Para una remodelación participativa y con cero desalojos de un barrio popular de Barcelona [blog]. https://repensarbonpastor.wordpress.com/ 